\title{
Profile of activities developed by community pharmacists: do they corroborate the precepts of the pharmaceutical profession?
}

\author{
Karolini de Faria Mota ${ }^{\circledR 1}$, André Oliveira Baldoni' ${ }^{1}$, \\ Elaine Cristina Coelho Baptista ${ }^{2}$, Tiago Marques dos Reis ${ }^{3}$, \\ Leonardo Régis Leira Pereira ${ }^{4}$, Mariana Martins Gonzaga do Nascimento ${ }^{5}$, \\ Paulo Roque Obreli-Neto ${ }^{6}$, Mariana Linhares Pereira ${ }^{1}$
}

\begin{abstract}
${ }^{1}$ Federal University of São João Del-Rei (UFSJ), São João Del-Rei, Minas Gerais, Brazil, ${ }^{2}$ Pharmacist of Hone Institute, Belo Horizonte, Minas Gerais, Brazil, ${ }^{3}$ Federal University of Alfenas (UNIFAL-MG), Alfenas, Minas Gerais, Brazil, ${ }^{4}$ School of Pharmaceutical Sciences of Ribeirão Preto, University of São Paulo (FCFRP-USP), Ribeirão Preto, Brazil, ${ }^{5}$ Federal University of de Minas Gerais (UFMG), Belo Horizonte, Brazil, ${ }^{6}$ Faculdades Integradas de Ourinhos (FIO), Ourinhos, São Paulo, Brazil
\end{abstract}

\begin{abstract}
Studies that addressed the profile of pharmaceutical activities and behaviors in community pharmacies in the last decades pointed to a gap between community pharmacy practice and the precepts of the profession. Facing the need to analyze whether the new legislation has impacted this scenario, the objective of this study was to describe the general profile and academic profile of community pharmacists, and the profile of the activities they develop, as well as to know their place of work. This is a descriptive study, to which all pharmacists in charge of community pharmacies in the metropolitan area of Belo Horizonte-MG $(\mathrm{n}=1624)$ were invited. Data collection was performed through a questionnaire validated online, from October to December 2017, via Google Docs ${ }^{\circledR}$. Responses were obtained from 109 pharmacists, most of them female, aged 31-40 years, being general graduates, and in private institutions. Pharmacotherapeutic follow-up, an activity linked to clinical management, is performed by only $37.60 \%$ of pharmacists, evidencing that there is still a lag in relation to the provision of clinical services by community pharmacists. Thus, we emphasize the importance of implementing the precepts established by Brazilian curricular guidelines for undergraduate pharmacy courses which focus on the development of clinical skills, since the insertion of the pharmacist into the health team and the provision of clinical services to the community can add new value to the use of medications, and contribute effectively to their rational use in Brazil.
\end{abstract}

Keywords: Community Pharmacy. Clinical Pharmacy. Pharmaceutical Education.

\section{INTRODUCTION}

The term "community pharmacy" refers to nonhospital and non-outpatient establishments (private or public), inserted in the community and providing care and pharmaceutical services (SBFC, 2018). For a long time the community pharmacy has been associated

*Correspondence: K. F. Mota. Federal University of São João Del-Rei (UFSJ). Rua Sebastião Gonçalves Coelho, 400. Bairro Chanadour, CEP 35.501-296, Divinópolis - MG, Brazil. Phone: +55 (37) 3690-4497. E-mail: karol_mota31@hotmail.com only with the supply of medication, due to a curative and hospital-centric (vertical) health model, centered on medical consultation and prompt care. However, social changes that promoted an increase in the prevalence of chronic non-communicable diseases led to changes in the health system, which started to be based on disease prevention and health promotion (horizontal) (Mendes, 2011). These transformations also brought about the need to expand the role of the community pharmacy in the Brazilian health system, characterizing it as an establishment of commercial, sanitary, technical and 
social dimensions, in order to meet the demands of society linked to the management of medication, and to the management of the process of use and results of the use of medication (Correr, Otuki, 2013).

Thus in 1997, Resolution 308 of the Federal Pharmacy Council (Conselho Federal de Farmácia $C F F$ ) established a framework for recognizing a new role for pharmacies in Brazil, and opened a debate on new practices related to assistance which have been gaining strength since then (CFF, 1997). An important legislation related to the activities of the community pharmacist is the Resolution of the Collegiate Board of Directors (Resolução da Diretoria Colegiada - RDC) $\mathrm{n}^{\circ}$. 44/2009 of the National Agency of Sanitary Surveillance (Agência Nacional de Vigilância Sanitária - ANVISA), which provides good pharmaceutical practices for sanitary control of the functioning, dispensation and commercialization of products, and the provision of pharmaceutical services, in Brazilian pharmacies and drugstores (ANVISA, 2009).

Legislation established by various governmental and institutional bodies represents an important advance in the regulation of pharmaceutical services in the community pharmacy, in the definition of quality criteria, and in the identification of the pharmacy as a health establishment (CFF, 2013; CFF, 2016; Brasil, 2017). Given this, the activities of the community pharmacist should be focused on medication and patients. Medication-related activities include logistical management (programming, acquisition, storage), magistral manipulation, quality control of products, and financial or personnel management. Pharmaceutical services focused on the patient, also called clinical services, are those in which there is direct interaction between the pharmacist and the patient, aiming at improving the process of medication use (CFF, 2016; Sánchez-Serrano, 2014; Cipolle et al., 2012).

However, studies carried out in the last decade that dealt with the profile of pharmaceutical activities and behaviors in community pharmacies pointed to a gap between community pharmacy practice and the precepts of the profession (Farina, Romano-Lieber, 2009; Bastos, Caetano, 2010, Oliveira et al., 2017). Given this context and the need to analyze if the new legislation has impacted on this scenario, the objective of this study was to describe the general profile and academic background, as well as the profile of the activities currently developed by community pharmacists.
These findings are up-to-date and contribute to the current scientific body, and consider constant changes in the profiles of professionals inserted in the market, mainly in community pharmacies, being facilities that frequently receive new graduates in Brazil (Oliveira et al., 2017; CFF, 2015). In addition, this research presents the profile of pharmacists in the metropolitan area of Belo Horizonte, and can contribute to clarify the community pharmacy reality and create improvement measures to the pharmaceutical services in this region.

\section{METHODS}

This is a descriptive study in which all pharmacists in charge of community pharmacies in the metropolitan area of Belo Horizonte-MG and registered with the Regional Pharmacy Council of Minas Gerais (Conselho Regional de Farmácia de Minas Gerais - CRF-MG) were invited. The invitation was made via e-mail to all pharmacists $(n=1624)$, and since the data collection was performed in an online environment a low response rate was expected (Marconi, Lakatos, 2003).

A validated questionnaire adapted, organized, and made available on the Google Docs ${ }^{\circledR}$ platform (Reis, 2013), was used to collect data from October to December 2017. In this case, questions 3, 11, 12, 13, 17 to $25,29,31$ to $40,42,45$ and 46 - from the original questionnaire - were excluded, and questions 5, 16 and 27 were modified in the alternative options provided. The variables that composed the questionnaire were organized into the following categories: general profile and academic background; work place profile; and activities performed in the exercise of the pharmaceutical profession.

The description of the general profile and academic background covered the following variables: gender (female/male), age (in years), type of degree (generalist or specialist), type of undergraduate institution (public or private), graduation year, and postgraduate activities performed.

Regarding the workplace profile, the variables collected were: type of pharmacy (independent or chain), number of pharmacists employed, weekly workload, time spent working in the pharmacy, and activities performed in some other place of work.

Finally, for the description of the activity profile developed by community pharmacists, it was required that the most commonly performed activities, according to Reis et al. (2018) be classified as "I never perform 
this" or "I perform this" (with different frequency and duration ratings). In addition, these activities were grouped into three distinct subcategories (technical management, administrative management, and clinical management activities), as follows (Correr, Otuki, Soler, 2011):

a. Technical management:

- Registration of the dispensing of medication that require prescription retention (in an electronic system).

- Verification of the period of validity of medication.

- Acquisition of products.

- Training of auxiliaries or employees.

b. Administrative management:

- Issuance of invoices of product entry/exit.

- Replacement of products on shelves

- Financial cash transactions (opening, closing and/or sales processing)

- Management activities

c. Clinical management

- Counseling of patients at the counter.

- Pharmacotherapeutic follow-up

d. Others:

- Cleaning of the establishment and/or shelves.

Among the possible clinical services to be developed in community pharmacies, we opted to evaluate the services of pharmacotherapy follow up and counseling of patients at the counter, considering that these are the clinical services that require a greater level of clinical knowledge and experience to be performed. For this reason, these would also be the services most extensively impacted by recent legislation.

The data collected were tabulated using Excel software and analyzed by descriptive statistics. Numerical summary measures such as frequencies and averages were calculated, which allowed us to make concise and quantitative statements that characterized the distribution of values in the population.

The work was approved by the Human Research Ethics Committee (CEPES) of the Federal University of São João Del-Rei (UFSJ), Centro Oeste Dona Lindu Campus (CCO), under opinion number 70609017.2.0000.5545.

\section{RESULTS AND DISCUSSION}

\section{General profile and academic background}

Responses were obtained from 109 pharmacists in charge of community pharmacies in the metropolitan area of Belo Horizonte-MG, with $76.1 \%$ being female and $43.1 \%$ between 31 and 40 years of age. As for their academic background profile, $67.0 \%$ graduated as generalist and $72.5 \%$ in private institutions, with the majority $(56.9 \%)$ graduating in the last seven years. In addition, among the most accomplished postgraduate activities are: congresses and short courses (conducted by $69.7 \%$ of pharmacists), improvements, and specializations (Table I). These findings corroborate the profile of the pharmacist in Brazil, according to the report developed by the Federal Pharmacy Council (CFF) in 2015 (CFF, 2015).

TABLE I - General profile and academic background of pharmacists in charge of community pharmacies in the metropolitan region of Belo Horizonte-MG $(\mathrm{n}=109 ; 2017)$

General profile and academic background of pharmacists

\begin{tabular}{lcc}
\hline General data & $\begin{array}{c}\text { Frequency } \\
\mathbf{n}(\%)\end{array}$ \\
\hline Gender & Female & $83(76.1 \%)$ \\
& Male & $26(23.9 \%)$ \\
& $20-30$ & $34(31.2 \%)$ \\
Age (years) & $31-40$ & $47(43.1 \%)$ \\
& $41-50$ & $21(19.3 \%)$ \\
& $>50$ & $7(6.4 \%)$ \\
\hline
\end{tabular}


TABLE I - General profile and academic background of pharmacists in charge of community pharmacies in the metropolitan region of Belo Horizonte-MG $(\mathrm{n}=109 ; 2017)$

General profile and academic background of pharmacists

\begin{tabular}{cc} 
Academic background & $\begin{array}{c}\text { Frequency } \\
\mathbf{n ~ ( \% )}\end{array}$ \\
\hline Generalist & $73(67.0 \%)$ \\
Industry qualification & $15(13.8 \%)$
\end{tabular}

Type of graduation Chemistry qualification $18(16.5 \%)$

\begin{tabular}{lcc} 
& Other & $2(1.8 \%)$ \\
& Prefer not to say & $1(0.9 \%)$ \\
\hline $\begin{array}{l}\text { Graduation } \\
\text { institution }\end{array}$ & Public & $30(27.5 \%)$ \\
& Private & $79(72.5 \%)$ \\
$\begin{array}{l}\text { Graduation } \\
\text { completion } \\
\text { time (in years } \\
\text { up to 2017) }\end{array}$ & $17-8$ & $16(14.7 \%)$ \\
& $<8$ & $29(26.6 \%)$ \\
& Missing & $2(56.9 \%)$ \\
& $\begin{array}{c}\text { Congresses and short } \\
\text { duration courses }\end{array}$ & $76(69.7 \%)$ \\
& Enhancement & $32(29.4 \%)$ \\
& Specialization ${ }^{2}$ & $52(47.7 \%)$
\end{tabular}

Postgraduate activities

Multi-professional residence

$2(1.8 \%)$

performed

$\begin{array}{cc}\text { Master's/Doctorate } & 8(7.3 \%) \\ \text { Others } & 7(5.6 \%) \\ \text { None } & 5(4.6 \%)\end{array}$

Prefer not to say $\quad 2(1.8 \%)$

1. It was not possible to identify clearly

2. Considering courses with a minimum workload of 360 hours

\section{Workplace profile}

In relation to the establishment where these pharmacists work, the majority (53.2\%) work in the pharmacy's headquarters (non-chain), which in the majority $(57.8 \%)$ have only one pharmacist, i.e., the participant of this research. The majority of pharmacists work between 40 and 44 hours per week (66.0\%) and have no employment elsewhere (87.2\%) (Table II).

TABLE II - Professional activity profile of pharmacists in charge of community pharmacies in the metropolitan region of Belo Horizonte-MG ( $\mathrm{n}=109 ; 2017)$

\begin{tabular}{ccc} 
Activity profile & $\begin{array}{c}\text { Frequency } \\
\text { n (\%) }\end{array}$ \\
\hline & Head office only & $58(53.2 \%)$ \\
& $\begin{array}{c}\text { More than one pharmacy } \\
\text { (not considered a chain) }\end{array}$ & $20(18.3 \%)$
\end{tabular}

Type of pharmacy Chain of pharmacies with centralized administration $13(11.9 \%)$

\begin{tabular}{|c|c|c|}
\hline & Franchise & $9(8.3 \%)$ \\
\hline & Prefer not to say & $9(8.3 \%)$ \\
\hline & One & $63(57.8 \%)$ \\
\hline $\begin{array}{l}\text { Number of } \\
\text { pharmacists }\end{array}$ & Two & $22(20.2 \%)$ \\
\hline $\begin{array}{l}\text { employed by } \\
\text { this pharmacy }\end{array}$ & More than two & $20(18.3 \%)$ \\
\hline & Prefer not to say & $4(3.7 \%)$ \\
\hline & $<40$ & $7(6.4 \%)$ \\
\hline Weekly workload & $40-44$ & $72(66.0 \%)$ \\
\hline (ho & $>44$ & $12(11.0 \%)$ \\
\hline & Missing* & $18(16.6 \%)$ \\
\hline
\end{tabular}


TABLE II - Professional activity profile of pharmacists in charge of community pharmacies in the metropolitan region of Belo Horizonte-MG $(\mathrm{n}=109 ; 2017)$

\begin{tabular}{lcc}
\hline Activity profile & $<1$ & $\begin{array}{c}\text { Frequency } \\
\text { n (\%) }\end{array}$ \\
\hline $\begin{array}{l}\text { Working time in } \\
\text { this pharmacy } \\
\text { (years) }\end{array}$ & $1-5$ & $54(49.5 \%)$ \\
& $6-10$ & $16(14.7 \%)$ \\
& $>10$ & $19(17.5 \%)$ \\
\hline $\begin{array}{l}\text { Professional } \\
\text { work elsewhere }\end{array}$ & Yes & $1(0.9 \%)$ \\
\hline
\end{tabular}

*It was not possible to identify clearly

\section{Profile of activities carried out by the community pharmacist}

Given these results, it can be observed that currently the activity less commonly performed by the community pharmacist is that of pharmacotherapeutic follow-up, linked to clinical management (Table III). This result is consistent with the profile of the Brazilian pharmacist, which shows that clinical services are performed by only $17.8 \%$ of them (CFF, 2015). Lack of time, user interest, and remuneration, are pointed out by pharmacists as barriers to the development of clinical services to the patient (Farina, Romano-Lieber, 2009; Dosea et al., 2017; Santos Junior et al., 2018; El Hajj, Al-Saeed, Khaja, 2016; Costa et al., 2017). In addition, studies that analyzed the knowledge and behavior profile of community pharmacists in relation to clinical services, evidenced a lack of preparation of these professionals to carry out such activities, indicating deficiencies in their academic background (Reis et al., 2015a; Reis et al., 2015b, Zekan et al., 2017).
TABLE III - Activities performed by pharmacists in charge of community pharmacies in the metropolitan area of Belo Horizonte $(\mathrm{n}=109 ; 2017)$

\begin{tabular}{|c|c|c|}
\hline Type of activity & Activities & $\begin{array}{l}\text { Percentage of } \\
\text { pharmacists } \\
\text { who perform } \\
\text { them }\end{array}$ \\
\hline \multirow{4}{*}{$\begin{array}{l}\text { Technical } \\
\text { management }\end{array}$} & $\begin{array}{l}\text { Verification of the } \\
\text { validity of products }\end{array}$ & $98.20 \%$ \\
\hline & $\begin{array}{c}\text { Training of auxiliaries } \\
\text { or employees }\end{array}$ & $90.80 \%$ \\
\hline & $\begin{array}{l}\text { Registration of } \\
\text { the dispensing of } \\
\text { medication that require } \\
\text { prescription retention }\end{array}$ & $89.90 \%$ \\
\hline & Product Acquisition & $74.30 \%$ \\
\hline \multirow{2}{*}{$\begin{array}{l}\text { Clinical } \\
\text { management }\end{array}$} & $\begin{array}{l}\text { Counseling of patients } \\
\text { at the counter }\end{array}$ & $96.30 \%$ \\
\hline & $\begin{array}{l}\text { Pharmacotherapeutic } \\
\text { follow-up }\end{array}$ & $37.60 \%$ \\
\hline \multirow{5}{*}{$\begin{array}{l}\text { Administrative } \\
\text { management }\end{array}$} & Issuance of invoices & $73.40 \%$ \\
\hline & $\begin{array}{c}\text { Replacement of } \\
\text { products on shelves }\end{array}$ & $88.10 \%$ \\
\hline & $\begin{array}{l}\text { Financial transactions } \\
\text { at the cash register }\end{array}$ & $55.10 \%$ \\
\hline & Management activities & $84.40 \%$ \\
\hline & Cleaning & $69.70 \%$ \\
\hline
\end{tabular}

In this context it is important to highlight the importance of clinical competence for performing various actions that should be developed by the community pharmacist prior to and during the use of medication by patients. Before the use of medication, by the proper prescription or indication of medication and in the appropriate dispensation, and to guarantee the right to information about the medication; and during the use of medication, in evaluating the effectiveness and safety of pharmacotherapy, in order to detect 
problems that can be solved, ensuring the achievement of positive outcomes (CFF, 2013). Federal law 13021/14 reinforces this important pharmaceutical role, defining pharmacies as health establishments, and giving more autonomy for the pharmacist to perform their clinical duties (Brasil, 2014).

Regarding the approach of this area of knowledge in pharmacy undergraduate courses, in 2017 the new National Curricular Guidelines (Diretrizes Curriculares Nacionais - DCN) were established. Compared to previous Brazilian guidelines, the increase in the number of passages that address clinical activities is noticeable, and consequently the focus on the development of skills related to clinical services has increased. In addition, the new DCN establishes that $50 \%$ of the curriculum must be composed of content belonging to the "Cuidados em Saúde" (Health Care) axis, which includes teaching of the competencies required to perform clinical services. Another significant change is the recommendation of a teaching process focused on new teaching methodologies (active methodologies) (Brasil, 2017).

However, a more prepared graduate regarding clinical pharmacy, will depend on the degree of commitment of higher education institutions to actually implement the precepts established by the guidelines of 2017. To this end, the orientation of training can be directed towards the integration between theory, simulation (activities of professional practice) and internship (activities in the service) linked to the disciplines related to pharmaceutical care, extending the scenarios of practice during the training of the pharmacist in college. This requires teachers with practical experience and engagement in the area, as well as infrastructure that enables these activities to be carried out (Ishizaki J, 2017; Saseen et al., 2017). In addition, educators should focus on active methodologies such as problem-based learning and community practices that integrate teaching-service-community (Araújo et al., 2017; CFF, 2016; Mesquista el al., 2015).

Thus, a new generation of community pharmacists presents high potential for providing services of high social relevance and integration to the health system, as well as the strategic position of the community pharmacy in the provision of health care. This insertion of the pharmacist into the health team and the provision of clinical services to the community can add new value to the use of medications, and contribute effectively to their rational use in Brazil (Correr, Otuki, 2013; Babar et al., 2018; Félix et al.,
2017; Rafferty et al., 2017), allowing the community pharmacy to combine the sale of services to the sale of medications and related.

This study had limitations in data collection because it was based on self-reporting and reminders of the participants, in addition to the reduced sample size. On the other hand, it is important to note the relevance of conducting this study, which describes the professional behavior profile of community pharmacists in a specific region of Brazil. Another important aspect of the work is the scarcity of research in this field so far.

Finally, even after the publication of legislation that establishes as essential the clinical performance of the pharmacist in Brazil, an important clinical service of pharmacotherapeutic follow-up is still rare in community pharmacies. This research considers that academic training enriching clinical competence, professionals, class councils, and government efforts for professional and infrastructure improvements, can generate a change in the behavior of professionals related to the provision of clinical services.

\section{REFERENCES}

Araújo PS, Costa EA, Guerra AA, Acurcio FDA, Guibu IA, Álvares J, et al. Atividades farmacêuticas de natureza clínica na atenção básica no Brasil. Rev. Saúde Públ. 2017;51(suppl 2).

Babar ZU, Kousar R, Murtaza G, Azhar S, Khan SA, Curley L. Randomized controlled trials covering pharmaceutical care and medicines management: a systematic review of literature. Res Social Adm Pharm. 2018 Jun 1;14(6):521-39.

Bastos CRG, Caetano R. As percepções dos farmacêuticos sobre seu trabalho nas farmácias comunitárias em uma região do estado do Rio de Janeiro. Ciênc. Saúde Colet. 2010;15(3):3541-3550.

Brasil. Agência Nacional de Vigilância Sanitária. ANVISA. Resolução da diretoria colegiada - RDC no 44, de 17 de agosto de 2009. Dispõe sobre Boas Práticas Farmacêuticas para o controle sanitário do funcionamento, da dispensação e da comercialização de produtos. Diário Oficial da União, Brasília, 18 de agosto de 2009. Seção 1, p. 78.

Brasil. Lei $\mathrm{n}^{\circ}$ 13.021, de 8 de agosto de 2014. Dispõe sobre o exercício e a fiscalização das atividades farmacêuticas. Diário Oficial da União, Brasília, 11 de agosto de 2014. Seção 1, p. 1.

Brasil. Ministério da Educação. Resolução $n^{0}$ 6, de 19 de outubro de 2017. Institui as Diretrizes Curriculares Nacionais do Curso de Graduação em Farmácia e dá outras providências. 
Diário Oficial da União, Brasília, 20 de outubro de 2017, Seção 1, p.30.

Cipolle RJ, Strand L, Morley P. Pharmaceutical Care Practice: The Patient-Centered Approach to Medication Management. 3 ed., New York: McGraw-Hill Medical. 2012.

Conselho Federal de Farmácia. CFF. Perfil do Farmacêutico no Brasil: Relatório. Brasília, Distrito Federal, 2015.

Conselho Federal de Farmácia. CFF. Resolução $n^{\circ}$ 308, de 2 de maio de 1997. Ementa: Dispõe sobre a Assistência Farmacêutica em farmácias e drogarias. Diário Oficial da União, Brasília, 22 de meio de 1997. Seção 1, p. 10695.

Conselho Federal de Farmácia. CFF. Resolução $n^{0} 585$ de 29 de agosto de 2013. Ementa: Regulamenta as atribuições clínicas do farmacêutico e dá outras providências. Diário Oficial da União, Brasília, 26 de setembro de 2013. Seção 1, p. 136.

Conselho Federal de Farmácia. CFF. Serviços farmacêuticos diretamente destinados ao paciente, à família e à comunidade: contextualização e arcabouço conceitual. Brasília, Distrito Federal, 2016.

Correr CJ, Otuki M. A prática farmacêutica na farmácia comunitária. Porto Alegre: Artmed; 2013.

Correr CJ, OTuki MF, Soler O. Assistência farmacêutica integrada ao processo de cuidado em saúde: gestão clínica do medicamento. Rev. Pan-Amaz. Saúde. 2011;2(3):41-49.

Costa FA, Scullin C, Al-Taani G, Hawwa AF, Anderson $\mathrm{C}$, Bezverhni Z, et al. Provision of pharmaceutical care by community pharmacists across Europe: Is it developing and spreading? J Eval Clin Pract. 2017 23(6):1336-47.

Dosea AS, Brito GC, Santos LM, Marques TC, Balisa-Rocha $\mathrm{B}$, Pimentel D, et al. Establishment, implementation, and consolidation of clinical pharmacy services in community pharmacies: perceptions of a group of pharmacists. Qual Health Res. 2017;27(3):363-73.

El Hajj MS, Al-saeed HS, Khaja M. Qatar pharmacists' understanding, attitudes, practice and perceived barriers related to providing pharmaceutical care. Int J Clin Pharm. 2016 Apr 1;38(2):330-43.

Farina SS, Romano-Lieber NS. Atenção farmacêutica em farmácias e drogarias: existe um processo de mudança? Saúde Soc. 2009;18(1):7-18.

Félix J, Ferreira D, Afonso-Silva M, Gomes MV, Ferreira C, Vandewalle B, et al. Social and economic value of Portuguese community pharmacies in health care. BMC Health Serv Res. 2017;17(1):606.

Ishizaki J. Improvement of Clinical Skills through Pharmaceutical Education and Clinical Research. Yakugaku zasshi. 2017;137(1):9-12.

Marconi MA, Lakatos EM. Fundamentos de metodologia científica. 5. ed., São Paulo: Atlas; 2003.

Mendes EV. As redes de atenção à saúde. Organização PanAmericana da Saúde (OPAS), 2011.

Mesquita AR, Souza WM, Boaventura TC, Barros IM, Antoniolli AR, Silva WB, et al. The effect of active learning methodologies on the teaching of pharmaceutical care in a Brazilian pharmacy faculty. PloS one. 2015;10(5):e0123141.

Oliveira NVBVD, Szabo I, Bastos LL, Paiva SP. Atuação profissional dos farmacêuticos no Brasil: perfil sociodemográfico e dinâmica de trabalho em farmácias e drogarias privadas. Saúde Soc. 2017;26:1105-1121.

Rafferty E, Yaghoubi M, Taylor J, Farag M. Costs and savings associated with a pharmacists prescribing for minor ailments program in Saskatchewan. Cost Eff Resour Alloc. 2017c;15(1):3.

Reis TM, Guidoni CM, Girotto E, Rascado RR, Mastroianni PC, Cruciol JM. Pharmaceutical care in Brazilian community pharmacies: knowledge and practice. Afr. J. Pharm. Pharmacol. 2015a, 9(9): 287-294.

Reis TM, Rocha KSS, Barros IMC, Santos LMC, Paixao FP, Almeida FHO, et al. Pharmacists skills in conducting clinical services in community pharmacies in urban areas of Northeast Brazil. Acta Farm. Bonaer. 2015b;34:725-731.

Reis TM, Zanetti ACB, Obreli Neto PR, Gonçalves AMRF, Baldoni AO, Guidoni CM, et al. Pharmacists in dispensing drugs (PharmDisp): construction and validation of a questionnaire to assess the knowledge for dispensing drug before and after a training course. Rev Eletr Farm . 2018;14:28-40.

Reis TM. Conhecimento e condutas dos farmacêuticos para a dispensação de medicamentos e a realização da atenção farmacêutica em drogarias [dissertação]. Ribeirão Preto: Universidade Federal do Rio Grande do Sul - UFRGS; 2013. Available from: https://lume. ufrgs.br/handle/10183/119379? fbclid=IwAR3B zXxgmDU1RWmaA__RLLj9-4hTpVMdwLFnsCiW6y8aBJMAkW29d1Qvk. Acessed in: Feb 2019. 
Sánchez-Serrano I. La Crisis Mundial de Los sistemas de Salud: Del laboratorio de investigaciones hasta la coma del paciente. Bogotá: Editora Elsevier Insights; 2014.

Santos Junior GA, Ramos SF, Pereira AM, Dosea AS, Araújo EM, Onozato T, et al. Perceived barriers to the implementation of clinical pharmacy services in a metropolis in Northeast Brazil. PloS one. 2018;22;13(10):e0206115.

Saseen JJ, Ripley TL, Bondi D, Burke JM, Cohen LJ, McBane S, et al. ACCP clinical pharmacist competencies. Pharmacotherapy. 2017;37(5):630-636.
Sociedade Brasileira de Farmácia Comunitária. SBFC. Quem somos [Internet]. Available from: http://www.sbfc.org.br/ site/paginas.php?id $=1$.

Zekan L, Mestrovic A, Perisin AS, Portolan M, Jambrek N, Jager S, et al. Clinical knowledge of community pharmacists in Croatia for detecting drug-related problems. Inter J Clin Pharm. 2017;39(6):1171-1174.

Received for publication on February $21^{\text {th }} 2019$ " Accepted for publication on $07^{\text {th }}$ May 2019 